\begin{tabular}{c} 
Volume and Issues Obtainable at Center for Sustainability Research and Consultancy \\
Journal of Business and Social Review in Emerging Economies \\
ISSN: 2519-089X (E): 2519-0326 \\
Volume 3: Issue 1 June 2017 \\
CSRᄃ \\
Journal homepage: $\underline{\text { www.publishing.globalcsrc.org/jbsee }}$ \\
\hline
\end{tabular}

\title{
SMEs' Views on Theory of Planned Behavior and Penalty Magnitude: Preliminary Findings from Nigeria
}

\author{
${ }^{1}$ Hannatu Yohanna Gimba, ${ }^{2}$ Idawati Ibrahim \\ ${ }^{1}$ School of Accountancy, Universiti Utara Malaysia, Malaysia, ghannatu@gmail.com \\ ${ }^{2}$ School of Accountancy, Universiti Utara Malaysia, Malaysia, idawati@uum.edu.my
}

\begin{tabular}{l}
\hline ARTICLE DETAILS \\
\hline History \\
Revised format: May 2017 \\
Available Online: June 2017
\end{tabular}

\section{Keywords}

Attitude,

Penalty Magnitude,

Perceived Behavioural

Control,

Subjective Norms,

VAT Compliance

JEL Classification:

C91, C99

\begin{abstract}
Purpose: This paper investigates the relationship between penalty magnitude, attitude towards VAT compliance, subjective norms and perceived behavioural control on VAT compliance intention among SMEs in Nigeria.

Methodology: Data was gathered through administration of 30 questionnaires. The respondents are SMEs in Kano, Nigeria. 23 indicator items were measured on 5-point Likert Scale from 1 (strongly disagree) to 5 (strongly agree). IBM SPSS Statistics 23 was employed as the primary statistical analysis tool for the study.

Findings: The result indicates positive relationship of penalty magnitude, subjective norms and perceived behavioural control on VAT compliance intention, while attitude towards VAT compliance has negative relationship with VAT compliance intention.

Implications: This study recommends a blend of economic and sociopsychological factors in tackling VAT compliance among SMEs, as that will encourage the SMEs to remit the VAT collections and also assist the policy makers to map-out policies that would ensure an effective management of VAT revenue and compliance among SMEs in Nigeria and other developing countries. Further studies on a larger number of respondents should be conducted to test the consistency of the results.
\end{abstract}

(C) 2017 The authors, under a Creative Commons Attribution-

NonCommercial 4.0

Corresponding author's email: ghannatu@gmail.com

Recommended citation: Gimba, H. Y. \& Ibrahim, I., (2017). SMEs' Views on the Theory of Planned Behaviour and Penalty Magnitude: Preliminary Findings from Nigeria. Journal of Business and Social Review in Emerging Economies, 3 (1) $39-50$.

DOI: https://doi.org/10.26710/jbsee.v3i1.180

\section{Introduction}

Value Added Tax (VAT) was introduced to increase the revenue base of a government that will accelerate economic growth (Salman, 2011). Furthermore, the revenue generated from VAT has a great impact to create jobs, build roads and infrastructures which will have a remarkable impact on the Nigerian economy (Izedonmi \& Okunbor, 2014). However, the contribution gotten from VAT is low as compared to other sources of revenue in Nigeria (FIRS, 2016b), which prompt the need to enquire reasons behind the compliance intention on VAT, especially among SMEs.

In the same vein, the visit of the Managing Director of International Monetary Fund (IMF) Ms. Christine Lagarde in January, 2016, on the need for the Nigerian government to increase the VAT rate, which is currently at 5\%, as that will boost the contribution of VAT and also increase the revenue base of the Nigerian government. However, the Nigerian minister of finance argues that, despite Nigeria operates one 
of the lowest VAT rate in the world, the issues surrounding VAT does not lie on the rate (5\%), but lies on the compliance rate. Which in her narrations, she mentioned that the VAT compliance rate is as low as 10\% (Tijjani, 2016).

In addition, there has been assumption that VAT was less vulnerable to evasion than other forms of taxation, since it is an indirect tax. However, the issues surrounding VAT non-compliance has been of great concern in developing countries (Webley \& Ashby, 2010). For example, VAT revenue losses in 2011 were as much as; $16 \%$ in France, $12 \%$ in the UK and 11\% in Australia (Barbone, Bird, \& VazquenzCaro, 2012).

VAT non-compliance is not only an issue for developed countries but is equally an issue in a developing country like Nigeria. For instance, the FIRS clamped down about nine managers of companies in FCT, Abuja that failed to remit VAT collections to the government (Okoyeuzu, 2013). The study further stated that, the FIRS also arrested the CEOs of seven companies in Lagos who failed to remit $\$ 2.17$ billion as accumulated VAT collections. In addition to VAT revenue loss in Nigeria, VAT collections dropped from $\$ 802.96$ billion in 2014 to $\$ 498.23$ billion in 2015 . In addition, the percentage of VAT collections to total revenue also dropped from $17 \%$ in 2014 to $13.5 \%$ in 2015 (FIRS, 2016b).

Nevertheless, the disturbing revelation as stated above on VAT revenue loss in Nigeria, the government cannot sit back and allow the challenges associated with non-remittance of VAT collections among the SMEs deter its chance of meeting up the expectations of IMF as one of the top 20 economies in the world by the year 2020 (International Monetary Funds, 2010).

In line with the expectations of the government, therefore, this study examined the relationship between the constructs of the Theory of Planned Behaviour (TPB) (attitude, subjective norms and perceived behavioural control), penalty magnitude and VAT compliance intention among SMEs in Nigeria. This is one of a kind, because there are limited studies conducted in Nigeria as relate to VAT compliance intention and the application of economic and socio-psychological factors into the TPB, which this study has achieved.

\section{Literature Review}

\subsection{VAT Compliance among SMEs}

As posited by Shaharuddin and Palil (2012), compliance is a social influence which involves action that is influenced by an individual to conform to a rule, policy or standard. Extending compliance to tax, Iskandar and Bhaduri (2016) are of the view that compliance requires filing of all required tax returns as at when due and in accordance with relevant regulations. In the same vein, tax compliance involves making tax payments and submitting relevant information required by the tax authorities as expected (Asnawi, 2013).

In Nigeria as a developing country, An SME who trades on VATable goods and services is expected to register and obtain a Tax Identification Number (TIN). TIN is issued by FIRS and it is free, with the intention to identify every taxpayer and it is expected to be used when making a transaction with the tax office (FIRS, 2016a). In addition to VAT operations in Nigeria, PwC (2014) posits that, tax officers are sent to monitor every registered SME from time to time to ensure that VAT collections are properly remitted to the authorities and as at when due. In addition, the tax officers provide necessary suggestions where necessary.

The motivating factors that influence SMEs to remit the VAT collections to the relevant authorities are issues for concern, which have led further research in the area for VAT compliance. Among the scholars that have carried out research in the area are; Adams and Webley (2001); Musau (2015); Naibei, Siringi and Musonera (2011); Walsh (2012); Webley, Adams and Elffers (2004). The result of their findings shows the factors influencing VAT compliance among SMEs can be economic and socio-psychological 
factors.

Economic factors such as detection probability, penalty, complexity of the tax system among others were found to positively influence VAT compliance among SMEs as posited by these scholars Ahmed, 2013; Alm, Kirchler, \& Muehlbacher, 2012; Chau \& Leung, 2009; Kirchler, 2007; Musau, 2015; Webley et al., 2002). In the same vein, socio-psychological factors such as social norms, personality, fairness in the tax system, trust in the tax administration, perception of government accountability, personal norms are also considered by scholars as factors influencing VAT compliance among SMEs (Bobek et al., 2012; Devos, 2014; Hauptman et al., 2014; Inasius, 2015; Richardson, 2006; Webley \& Ashby, 2010)

Although, the factors mentioned have played role in ensuring VAT compliance among SMEs but the role of penalty magnitude cannot be overlooked, which this study has achieved.

\subsection{Penalty Magnitude (PM)}

The laxity of some SMEs have made penalty to be the only option to implement compliance behaviour. Penalty in compliance is the process of increasing power of the authorities to ensure enforced compliance (Kirchler, Hoelzl, \& Wahl, 2008). Also, Nyamwanza, Mavhiki, Mapetere and Nyamwanza (2014) in their studies revealed that penalty is found to be the most effective variable in enforcing compliance. In addition, other studies conducted on enforce compliance, found that penalty has played a great role to deter, motivate and correct improper behaviour of SMEs (Poppelwell, Kelly, \& Wang, 2012; Wenzel, 2001).

Furthermore, Kirchler (2007) states that compliance is enforced through application of tax penalties on taxpayers that are not willing to pay or remit the VAT collections as the case may be. In addition, penalties have been found to be the most effective tools in Zimbabwe. As most SMEs evade remitting tax collections by bribing the tax collection officers through keeping two set of records and sometimes relocating to new sites without notifying the tax officials (Nyamwanza et al., 2014). However, Swistak (2016) posits that penalties have the potential to work effective if used as an auxiliary means of delivery and implementing a sound compliance strategy.

With the above view by Swistak (2016), this study will be discussing the constructs of the theory of planned and relate them to VAT compliance intention among SMEs in Nigeria.

\subsection{The Theory of Planned Behaviour (TPB)}

TPB is an improved version of the Theory of Reasoned Action (TRA), which was developed by Ajzen (1985). The TRA assumes that human beings behave in a sensible manner, and the constructs that predict intention under the TRA are attitude and subjective norms (Ajzen \& Fishbein, 1977). While TPB assumes behaviour of an individual within the society are under the influence of definite factors, originate from certain reasons and emerged in a planned way (Ajzen, 1985). He further stated that the constructs that predict intention are attitude, subjective norms and perceived behavioral control. That is, perceived behavioural control is the addition to the two determinants of intention as described in TRA.

\subsubsection{Attitude towards VAT Compliance (AVC)}

Ajzen and Fishbein (2005) conceptualized attitude as the amount of affection which lies for or against an object been observed. In the same vein, Helhel and Ahmed (2014) suggest that attitude is the cause of an individual's behaviour towards another person, event or object. Furthermore, an attitude towards any object is the function of one's belief about the object and the implicit evaluative response associated with those beliefs (Benk, Cakmak, \& Budak, 2011). As posited by other scholars, attitude refers to the individual's evaluation of the target behavior and is formed based on perceptions or knowledge from prior experience, and the target behaviour can be favorable or unfavorable (Ajzen, 2012; Langham, Paulsen, \& Hartel, 2012). 
In relating attitude of SMEs to VAT compliance, some studies posit positive relationship between attitudes and tax (VAT inclusive) compliance (Benk et al., 2011; Nkwe, 2013), while other studies found that the AVC depends on how the SME or taxpayer is treated by the government. That is, the SMEs expect the government to provide its citizens with the basic needs, so as the value of the tax they are paying/remitting will be felt (Nyamwanza et al., 2014; Oladipupo \& Izedonmi, 2013). The second construct that predicts intention in TPB is the subjective norms.

\subsubsection{Subjective Norms (SN)}

Subjective norms capture the opinions of social reference groups (such as family, friends and co-workers) regarding whether the individual should engage in the behavior or not (Huda, Rini, Mardoni, \& Putra, 2012). In another study, $\mathrm{SN}$ is seen as a social pressure put on another individual to perform a certain behaviour (White, Smith, Terry, Greenslade, \& McKimmie, 2009).

In relating $\mathrm{SN}$ to compliance intention, some studies posited no significant influence to intention (Huda et al., 2012; Trivedi, Shehata, \& Mestelman, 2005), while the study conducted by Bobek et al. (2012) showed a direct relationship between subjective norms and compliance. The last construct that predicts intention in the TPB and it is the addition to the TRA, is the perceived behaviour control, which will be discussed in the subsequent sub-head.

\subsubsection{Perceived Behavioural Control (PBC)}

PBC denotes the ease or difficulty in performing a behavior. In addition, it can be an act of observing a behavior and the consequences of that behavior, which one can recall the sequence of events and use this information to guide subsequent behaviors (Devos, 2012; Ebimobowei \& Peter, 2013; Kautonen, van Gelderen, \& Fink, 2015).

Relating PBC to VAT compliance, White et al. (2009) in their study described PBC as a significant predictor of behavioural intention. In the same vein, participants had a stronger intention to perform an activity, if they perceived a high level of PBC. Furthermore, PBC was also found to play a significant predictor in decision making (St. John, Edwards-Jones, \& Jones, 2010). Therefore, with the relevant literature discussed, theoretical support provided and the TPB which has been previously discussed, the research framework is presented in figure 1.

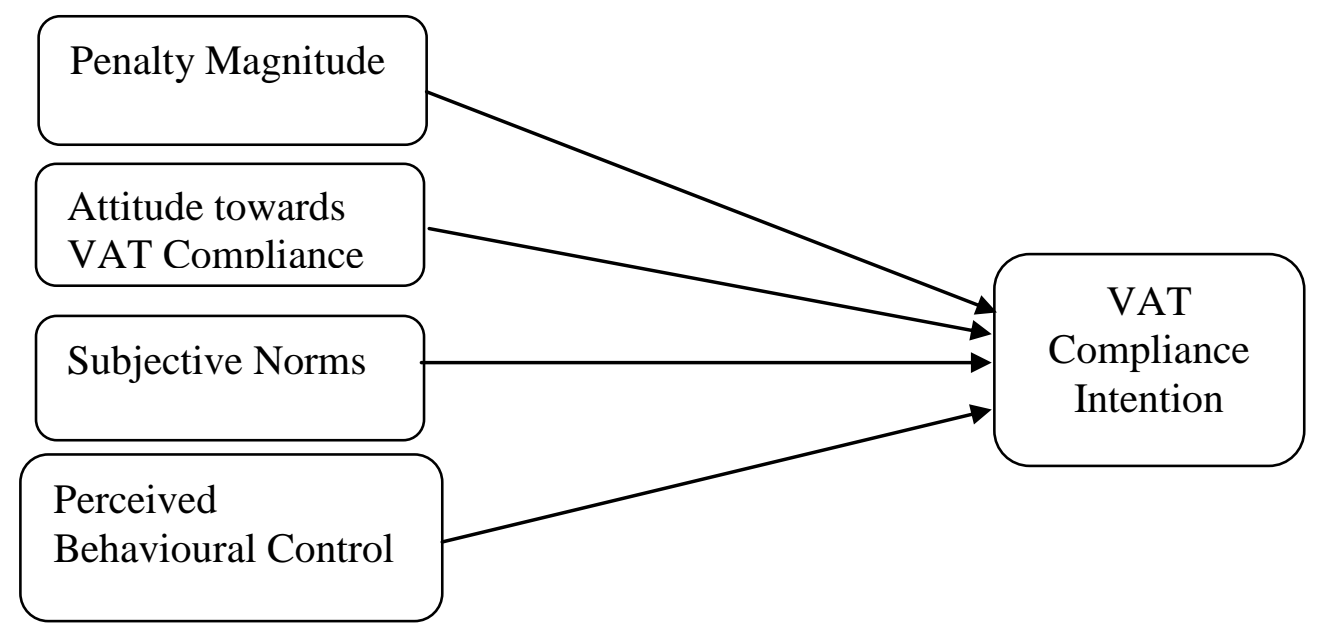

Figure 1 Research Framework

Based on the research framework in Figure 1, the study proposed the following hypotheses for validation: $\mathrm{H}_{1}$ : There is a positive relationship between penalty magnitude and VAT compliance intention among SMEs.

$\mathrm{H}_{2}$ : There is a positive relationship between attitude towards VAT compliance and VAT compliance 
intention.

$\mathrm{H}_{3}$ : There is a positive relationship between subjective norms and VAT compliance intention among SMEs.

$\mathrm{H}_{4}$ : There is a positive relationship between perceived behavioural control and VAT compliance intention among SMEs.

\section{Research Methodology}

The Small and Medium Enterprises (SMEs) that are registered for VAT purposes and are operating in Nigeria are those targeted for this study. Furthermore, the sample size was drawn from Kano state, northwest Nigeria. Kano state has about $60 \%$ of the SMEs in the north-west, Nigeria. A total of 40 questionnaires were personally administered using cluster sampling technique, based on geographical location of the SMEs in the industrial areas of Kano state, north-west Nigeria. A total of 30 questionnaires were retrieved, representing $75 \%$ response rate. The questionnaire was divided into four parts: perceptions on VAT compliance, VAT compliance, demographic information, comments and suggestion.

\subsection{Demographic Information of Respondents}

The demographic information of the respondents as presented in Table 1 indicates that about $53.3 \%$ of the respondents were male and $14.7 \%$ were females and approximately $86.7 \%$ of the respondents do not make use of tax agents. See Table 1 for a comprehensive detail of demographic information.

Table 1: Demographic Information of the Respondents

\begin{tabular}{lcc}
\hline Category & $\begin{array}{c}\text { Frequency } \\
(\mathbf{N = 3 0 )}\end{array}$ & $\begin{array}{c}\text { Percentage } \\
\text { (Total=100) }\end{array}$ \\
\hline Gender & & \\
Male & 16 & 53.3 \\
Female & 14 & 46.7 \\
\hline
\end{tabular}

Table 1: (Continued)

\begin{tabular}{|c|c|c|}
\hline Category & $\begin{array}{c}\text { Frequency } \\
(\mathbf{N}=\mathbf{3 0})\end{array}$ & $\begin{array}{l}\text { Percentage } \\
(\text { Total }=100)\end{array}$ \\
\hline \multicolumn{3}{|l|}{ Age } \\
\hline Below 15 years & 0 & 0 \\
\hline 15 years -30 years & 11 & 36.7 \\
\hline Above 30 years & 19 & 63.3 \\
\hline \multicolumn{3}{|l|}{ Position in the Business } \\
\hline Owner/manager & 11 & 36.7 \\
\hline Accountant/finance officer & 7 & 23.3 \\
\hline Admin/clerical officer & 8 & 26.7 \\
\hline Others & 4 & 13.3 \\
\hline \multicolumn{3}{|c|}{ How long Business Established } \\
\hline Less than 1 year & 2 & 6.7 \\
\hline 1 year -5 years & 6 & 20.0 \\
\hline 6 years -10 years & 14 & 46.7 \\
\hline Above 10 years & 8 & 26.6 \\
\hline \multicolumn{3}{|l|}{ Business Annual Turnover } \\
\hline Less than $¥ 5 \mathrm{~m}$ & 11 & 36.7 \\
\hline$\$ 5 \mathrm{~m}-\$ 50 \mathrm{~m}$ & 10 & 33.3 \\
\hline$\# 51 \mathrm{~m}-\# 200 \mathrm{~m}$ & 6 & 20.0 \\
\hline Above $\$ 200 \mathrm{~m}$ & 3 & 10.0 \\
\hline \multicolumn{3}{|l|}{ Employees in the Company } \\
\hline Less than 10 persons & 0 & 0 \\
\hline 10 persons -49 persons & 23 & 76.7 \\
\hline
\end{tabular}




\begin{tabular}{lcc}
\hline 50 persons -199 persons & 6 & 20.0 \\
Above 200 persons & 1 & 3.3 \\
& & \\
Nature of Business & 3 & 10.0 \\
Educational services & 9 & 30.0 \\
Wholesale/retail & 3 & 10.0 \\
Manufacturing & 10 & 33.3 \\
Accommodation and food & 5 & 16.7 \\
Others & 4 & 13.3 \\
Tax Agent & 46 & 86.7 \\
Yes & 26 & \\
No & & \\
\hline
\end{tabular}

\subsection{Measurements of Variables for the Study}

This study measured all the variables using a five-point Likert scale ranging from ' 1 ' "strongly disagree" to ' 5 ' "strongly agree". Furthermore, all the items used for this study were adapted from previous studies with modifications. For instance, the items for VAT compliance intention (VCI) were five, using a hypothetical VAT scenario as adapted from Efebera et al. (2004) and Langham et al. (2012). The items for penalty magnitude were five as adapted from Efebera et al. (2004) and Nyamwanza et al. (2014). In the same vein, the study used five items each for attitude towards VAT compliance, subjective norms and perceived behavioural control as adapted from Saad (2011).

\section{Results and Discussion}

\subsection{Reliability Analysis}

This study used the Cronbach's alpha to test the reliability of measures and also to test the internal consistency of the measurement items. Cronbach's alpha was used because it is widely recommended for social science research (Hair, Black, Babin, \& Anderson, 2010; Sekaran \& Bougie, 2010). As posited by Hair et al. (2010) a Cronbach's alpha coefficient of at least .70 is considered sufficient and acceptable. The results of the Cronbach's alpha for this study is shown in Table 2 .

Table 2: Reliability Test

\begin{tabular}{lcc}
\hline Variable & Items & Alpha \\
\hline Penalty Magnitude & 5 & .734 \\
Attitude towards VAT Compliance & 4 & .738 \\
Subjective Norms & 4 & .716 \\
Perceived Behavioural Control & 5 & .849 \\
VAT Compliance Intention & 5 & .719 \\
\hline
\end{tabular}

Table 2 shows that the calculated value of alpha for each of the variable is above .70 . Therefore, it concludes that the instruments used to measure the constructs for the study has fulfilled the reliability test, which is in line with Hair et al. (2010) on at least .70 is considered sufficient and acceptable.

\subsection{Descriptive Statistics}

Descriptive statistics are often used to describe the basic characteristics of the data. Therefore, the mean, standard deviation, maximum and minimum of each variable were obtained through descriptive statistics using IBM SPSS statistics 23. The results of the descriptive statistics are shown in Table 3 to 7. (Note: $\mathrm{M}=$ Mean, $\mathrm{Std}=$ Standard Deviation, Min= Minimum, Max= Maximum).

\subsubsection{VAT Compliance Intention}

A VAT scenario was used and the options to measure the VAT compliance intention of SMEs are VCI1 to VCI5. The result as seen in Table 3 reveals that mean scores range from 3.43 to 4.17 and standard deviation from 1.206 to 1.402 . This indicates that majority of the respondents' (VCI2) will keep the money until FIRS comes for audit, which implies the compliance intention is relatively low. 
Table 3: Descriptive Statistics for VCI

\begin{tabular}{rlcccc}
\hline Code & \multicolumn{1}{c}{ Statement } & Min & Max & M & Std \\
\hline VCI & VAT Compliance Intention & $\mathbf{1}$ & $\mathbf{5}$ & $\mathbf{3 . 7 9}$ & $\mathbf{. 6 7 7}$ \\
VCI1 & $\begin{array}{l}\text { Audu should declare the } \# 100,000 \text { to FIRS because the amount } \\
\text { is large }\end{array}$ & 1 & 5 & 3.67 & 1.322 \\
VCI2 & $\begin{array}{l}\text { Audu should keep the N100,000 until FIRS comes for audit } \\
\text { VCI3 }\end{array}$ & 1 & 5 & 4.17 & 1.206 \\
& $\begin{array}{l}\text { Despite the N100,000 is small, Audu should still declare the } \\
\text { amount to FIRS }\end{array}$ & 1 & 5 & 4.03 & 1.273 \\
VCI4 & $\begin{array}{l}\text { Audu should keep the \#100,000 as part of his profit } \\
\text { VCI5 }\end{array}$ & 1 & 5 & 3.63 & 1.402 \\
& $\begin{array}{l}\text { Audu should make effort to declare the total of \#400,000 at } \\
\text { once }\end{array}$ & 1 & 5 & 3.43 & 1.278 \\
\hline
\end{tabular}

\subsubsection{Penalty Magnitude}

The views of the respondents on penalty magnitude were measured using PM1 to PM5. The result (refer to Table 4) reveals that mean scores range from 2.83 to 3.33 and standard deviation from 1.326 to 1.533. Specifically, the results reveal most SMEs feel the penalty impose by the government is relatively low, hence, the government should increase the penalty.

Table 4: Descriptive Statistics for PM

\begin{tabular}{llcccc}
\hline Code & \multicolumn{1}{c}{ Statement } & Min & Max & M & Std \\
\hline PM & Penalty Magnitude & $\mathbf{1}$ & $\mathbf{5}$ & $\mathbf{3 . 1 7}$ & $\mathbf{. 6 0 6}$ \\
PM1 & The penalty for VAT non-compliance is very high & 1 & 5 & 2.83 & 1.533 \\
PM2 & SMEs can still cheat even with the presence of penalty & 1 & 5 & 3.03 & 1.450 \\
PM3 & $\begin{array}{l}\text { I will be in serious trouble if the FIRS finds out that I didn't } \\
\text { remit the VAT collections }\end{array}$ & 1 & 5 & 3.27 & 1.461 \\
PM4 & $\begin{array}{l}\text { The penalty of non-compliance is very low. That is, business as } \\
\text { usual }\end{array}$ & 1 & 5 & 3.37 & 1.326 \\
PM5 & $\begin{array}{l}\text { Other SMEs that are not complying are not being sanctioned by } \\
\text { the government }\end{array}$ & 1 & 5 & 3.33 & 1.373 \\
\hline
\end{tabular}

\subsubsection{Attitude towards VAT Compliance}

The attitude towards VAT compliance was measured using AVC1 to AVC4 and the results revealed that most of the respondents believe that they will be pleased if they remit the VAT collections to the relevant tax authorities. On a whole, the mean score range from 4.07 to 4.33 and the standard deviation is from 1.398 to 1.530 (refer to Table 5).

Table 5: Descriptive Statistics for AVC

\begin{tabular}{|c|c|c|c|c|c|}
\hline Code & Statement & Min & Max & $\mathbf{M}$ & Std \\
\hline AVC & Attitude towards VAT Compliance & 1 & 5 & 4.18 & .804 \\
\hline AVC1 & $\begin{array}{l}\text { I would be upset if I don't remit the VAT collections to the } \\
\text { government }\end{array}$ & 1 & 5 & 4.13 & 1.502 \\
\hline AVC2 & $\begin{array}{l}\text { I would feel guilty if I don't remit the VAT collections to the } \\
\text { government }\end{array}$ & 1 & 5 & 4.07 & 1.530 \\
\hline AVC3 & $\begin{array}{l}\text { I would feel pleased if I remit the VAT collections to the } \\
\text { government }\end{array}$ & 1 & 5 & 4.33 & 1.398 \\
\hline AVC4 & $\begin{array}{l}\text { The likelihood of being audited by FIRS is very high, so I will } \\
\text { not be pleased if I don't comply }\end{array}$ & 1 & 5 & 4.20 & 1.518 \\
\hline
\end{tabular}

\subsubsection{Subjective Norms}

The expectations from family, peers and co-workers to VAT compliance intention was measured using SN1 to SN4 and the results revealed that the mean score range from 3.97 to 4.50 and the standard deviation from .572 to .988 . This suggests that the expectation from, family, peers and co-workers have an influence on VAT compliance among SMEs (refer to Table 6). 
Table 6: Descriptive Statistics for SN

\begin{tabular}{clcccc}
\hline Code & \multicolumn{1}{c}{ Statement } & Min & Max & M & Std \\
\hline SN & $\begin{array}{l}\text { Subjective Norms } \\
\text { SN1 }\end{array}$ & $\mathbf{1}$ & $\mathbf{5}$ & $\mathbf{4 . 2 1}$ & $\mathbf{. 6 5 7}$ \\
My family and peers will expect me to report the VAT & 1 & 5 & 4.07 & .980 \\
collections to FIRS as at when due & $\begin{array}{l}\text { My family and peers will approve if I don't remit the VAT } \\
\text { collections to the government } \\
\text { My family and peers would remit the VAT collections if they } \\
\text { are faced with similar situation } \\
\text { Sy co-workers would expect me to remit the VAT collections } \\
\text { to the government }\end{array}$ & 1 & 5 & 4.30 & .988 \\
SN4 & 1 & 5 & 4.50 & .572 \\
\hline
\end{tabular}

\subsubsection{Perceived Behavioural Control}

The ease and difficulty of complying by the SMEs was measured using PBC1 to PBC5 and the results revealed that the mean scores range from 3.73 to 4.17 and the standard deviation from 1.262 to 1.648. This means that most of the respondents feel that due to the effectiveness of detection, it is difficult not to comply (refer to Table 7).

Table 7: Descriptive Statistics for PBC

\begin{tabular}{|c|c|c|c|c|c|}
\hline Code & Statement & Min & Max & $\mathbf{M}$ & Std \\
\hline PBC & Perceived Behavioural Control & 1 & 5 & 3.91 & .751 \\
\hline PBC1 & $\begin{array}{l}\text { Due to the effectiveness of detection by the authorities, it is } \\
\text { difficult for me not to comply }\end{array}$ & 1 & 5 & 4.17 & 1.262 \\
\hline PBC2 & $\begin{array}{l}\text { With the magnitude of penalty it is easy for me to remit the } \\
\text { VAT collections to the authority }\end{array}$ & 1 & 5 & 3.73 & 1.617 \\
\hline PBC3 & There is threat of detection and audit & 1 & 5 & 3.80 & 1.648 \\
\hline PBC4 & $\begin{array}{l}\text { It is easy for me to remit the VAT collections to the authority, } \\
\text { even without penalty }\end{array}$ & 1 & 5 & 3.93 & 1.413 \\
\hline PBC5 & $\begin{array}{l}\text { I will not avoid remitting the VAT collections to the authorities } \\
\text { even with the presence of detection and penalty }\end{array}$ & 1 & 5 & 3.93 & 1.596 \\
\hline
\end{tabular}

\section{Multiple Regression Analysis}

To test the hypotheses on the direct relationship between PM, AVC, SN and PBC (independent variables) and VCI (dependent variable), multiple regression analysis was used as recommended by Hair et al. (2010). The results of the analysis are presented in Table 8 and 9.

Table 8: Summary of Regression Model

\begin{tabular}{lccccc}
\hline Model & $\mathbf{R}$ & R Square & $\begin{array}{c}\text { Adjusted R } \\
\text { Square }\end{array}$ & $\begin{array}{c}\text { Std. Error of the } \\
\text { Estimate }\end{array}$ & $\begin{array}{c}\text { Durbin- } \\
\text { watson }\end{array}$ \\
\hline 1 & $.804 \mathrm{a}$ & .647 & .590 & 2.166 & 2.430 \\
\hline
\end{tabular}

a. Predictors: (Constant), PM, AVC, SN, PBC.

b. Dependent Variable: VCI

The result as measured by adjusted $\mathrm{R}^{2}$ indicates the effect of the independent variables (PM, AVC, SN, $\mathrm{PBC}$ ) over the dependent variable (VCI). This explains that the extent to which the independent variables affect the dependent variable is about 0.590 or $59.0 \%$ as seen in Table 8 .

Table 5: Coefficient of the Regression

\begin{tabular}{rlrrrrrr}
\hline \multicolumn{7}{c}{$\begin{array}{c}\text { Standardized } \\
\text { Mnstandardized Coefficients } \\
\text { Model }\end{array}$} & \multicolumn{2}{c}{$\begin{array}{c}\text { Coefficients } \\
\text { B }\end{array}$} & \multicolumn{2}{c}{ Std. Error } & \multicolumn{1}{c}{ T } & \multicolumn{1}{c}{ p-Value } \\
\hline & PM & .393 & .157 & .352 & 2.509 & .019 \\
& AVC & -.176 & .105 & -.210 & -1.674 & .107 \\
& SN & .366 & .172 & .355 & 2.134 & .043 \\
& PBC & .309 & .136 & .344 & 2.267 & .032 \\
\hline
\end{tabular}

Note: Significance levels are: $p<.05 ; \mathrm{p}<.10$ 
Going by the results of the $t$ values (refer to Table 9), PM, SN and PBC show a positive relationship with VAT compliance intention. Therefore, the hypotheses H1, H3 and H4 formulated for the study should be accepted. The result of SN and PBC is consistent with previous findings, which state a positive relationship with compliance (Benk et al., 2011; Bobek et al., 2012; Nkwe, 2013). In the same vein, the result on PM and VAT compliance is in consistent with previous studies, which found a positive significant relationship (Nyamwanza et al., 2014; Poppelwell et al., 2012).

However, the result on AVC shows a negative relationship with VAT compliance. Which can be linked to the findings from studies about the attitude towards VAT compliance depends on how the SME is treated by the government (Nyamwanza et al., 2014; Oladipupo \& Izedonmi, 2013). In the same vein, the comments given by the respondents in the questionnaire also support the assertion that attitude towards compliance will be effective if other predictors are considered alongside attitude. Some of the comments are:

"My attitude towards VAT compliance is influenced by the situation at that moment. If the government gives me a reason to see the importance of remitting VAT collections, I remit as expected".

"My attitude towards VAT compliance depends on perceived fairness in the tax system".

Hence, the hypothesis $\left(\mathrm{H}_{2}\right)$ formulated in this study for AVC should be rejected.

\section{Implications and Conclusion}

With the VAT revenue loss experienced in Nigeria, yet there are limited studies on the factors influencing the VAT compliance intention especially among SMEs. This study delves into the area to test the relationship between penalty magnitude through an expansion of the theory of planned of planned behaviour. The variable (PM) was carefully chosen because of the suggestions of Nyamwanza et al. (2014) on the role played by penalty to aid compliance among the SMEs. As most SMEs either close temporarily their businesses or relocate to other cities so as to avoid remitting tax (VAT inclusive) collections to the tax authority.

The study employed descriptive statistics and multi regression to analyse the data collected. Where the study reveals that most SMEs generally believed that penalty, subjective norms, perceived behavioural control have positive relationship on their compliance intentions, while attitude has a negative relationship on VAT compliance intention. Theoretically, the information obtained from this study would be beneficial to add to the limited literature on VAT compliance available in Nigeria as well as other developing countries. Also, researchers may use these identified variables for future research.

From the policy makers' perspectives, the information from this study will assist tax authority to develop appropriate strategies that will assist and ease the SMEs in remittance of VAT collections in Nigeria as well as other developing countries. In addition, the study will assist the policy makers to map-out policies that would ensure an effective management and tackling the issues surrounding VAT non-compliance among SMEs in Nigeria.

Finally, the study was focused on 30 SMEs in Nigeria; hence having a larger number of respondents may give a different perception on VAT compliance. Therefore, the study suggests having a larger sample to check the consistency of the results.

\section{References}

Adams, C., \& Webley, P. (2001). Small business owners' attitudes on VAT compliance in the UK. Journal of Economic Psychology, 22(2), 195-216. http://doi.org/10.1016/S0167-4870(01)00029-0

Ahmed, A. (2013). Determinants of tax compliance : The case of Jimma town.

Ajzen, I. (1985). From intentions to actions: A theory of planned behavior. Action Control: From Cognition to Behavior, 11-39. http://doi.org/10.1007/978-3-642-69746-3_2 
Ajzen, I. (2012). Martin fishbein's legacy: The reasoned action approach. American Academy of Political and Social Science, 640(1), 11-27. http://doi.org/10.1177/0002716211423363

Ajzen, I., \& Fishbein, M. (1977). Attitude-behavior relations: A theoretical analysis and review of empirical research. Psychological Bulletin, 84(5), 888-918. http://doi.org/10.1037/00332909.84.5.888

Ajzen, I., \& Fishbein, M. (2005). The influence of attitudes on behavior. Handbook of Attitudes and Attitude Change: Basic Principles, (January 2005), 173-221.

Alm, J., Kirchler, E., \& Muehlbacher, S. (2012). Combining psychology and economics in the analysis of compliance: From enforcement to cooperation. Economic Analysis \& Policy, 42(2), 133-152. http://doi.org/http://dx.doi.org/10.1016/S0313-5926(12)50016-0

Asnawi, M. (2013). The impact of audit rate, perceived probability of audit on tax compliance decision: A laboratory experiment study. Journal of Indonesian Economy and Business, 28(2), 292-307.

Barbone, L., Bird, R., \& Vazquenz-Caro, J. (2012). The costs of VAT: A review of the literature. Case Network Reports, (106).

Benk, S., Cakmak, A. F., \& Budak, T. (2011). An investigation of tax compliance intention: A theory of planned behavior approach. European Journal of Economics, Finance and Administrative Sciences, 28(28), 180-188.

Bobek, D. D., Hageman, A. M., \& Kelliher, C. F. (2012). Analyzing the role of social norms in tax compliance behavior. Journal of Business Ethics. http://doi.org/10.1007/s 10551-012-1390-7

Chau, G., \& Leung, P. (2009). A critical review of Fischer tax compliance model : A research synthesis. Journal of Accounting and Taxation, 1(2), 034-040. http://doi.org/10.5897/JAT09.021

Devos, K. (2012). The impact of tax professionals upon the compliance behavior of Australian individual taxpayers. Revenue Law Journal, 22(1), 1. Retrieved from http://qut.summon.serialssolutions.com/2.0.0

Devos, K. (2014). Factors influencing individual taxpayer compliance behaviour. Factors Influencing Individual Taxpayer Compliance Behaviour, 9789400774, 1-342. http://doi.org/10.1007/978-94007-7476-6

Ebimobowei, A., \& Peter, E. G. (2013). A causality analysis between tax audit and tax compliance in Nigeria. European Journal of Business and Management Www.iiste.org ISSN 2222-1905 (Paper) ISSN 2222-2839 (Online) Vol.5, No.2, 2013, 5(2), 107-121. Retrieved from http://www.iiste.org/Journals/index.php/EJBM/article/view/3934/3992

Efebera, H., Hayes, D. C., Hunton, J. E., O 'neil, C., Jardine-Tweedie, L., \& Wright, P. C. (2004). Tax compliance intentions of low-income individual taxpayers. Journal of Managerial Psychology Iss, 13(8), 534-543. http://doi.org/10.1016/S1474-7979(04)07001-2

FIRS. (2016a). Basic tips to complying with Nigerian tax laws. Retrieved from www.firs.gov.ng

FIRS. (2016b). Reporting and statistics department. Retrieved from www.firs-ng.org

Hair, J. F., Black, W. C., Babin, B. J., \& Anderson, R. E. (2010). Multivariate data analysis. Vectors. http://doi.org/10.1016/j.ijpharm.2011.02.019

Hauptman, L., Horvat, M., \& Korez-Vide, R. (2014). Improving tax administration's services as a factor of tax compilance: The case of tax audit. Lex Localis, 12(3), 481-501. http://doi.org/10.4335/12.3.481-501(2014)

Helhel, Y., \& Ahmed, Y. (2014). Factors affecting tax attitudes and tax compliance : A survey study in Yemen, 6(22), 48-58.

Huda, N., Rini, N., Mardoni, Y., \& Putra, P. (2012). The analysis of attitudes , subjective norms, and behavioral control on muzakki's intention to pay zakah. International Journal of Business and Social Science, 3(22), 271-279.

Inasius, F. (2015). Tax compliance of small medium enterprises in Indonesia: A case of retailer. Global Conference on Business and Finance Proceedings, 10(1), 87-93.

International Monetary Funds. (2010). World economic outlook database: Nominal GDP list of countries for the $2009 . \quad$ year 20 Retrieved www.imf.org./eternal/pubs/ft/weo/2010/01/weodata/weorept.aspx

Iskandar, D., \& Bhaduri, A. (2016). The determinants of compliance with environmental tax: Behavioural 
study motivated by the case of Indonesia. African Journal of ..., 11(1), 33-46. Retrieved from http://ageconsearch.umn.edu/bitstream/233847/2/4 Iskandar et al.pdf

Izedonmi, F. I. O., \& Okunbor, J. A. (2014). The role of value added tax on economic growth of Nigeria. British Journal of Economics, Management \& Trade, 4(12), 156. http://doi.org/10.9734/BJEMT/2014/11013

Kautonen, T., van Gelderen, M., \& Fink, M. (2015). Robustness of the theory of planned behavior in predicting entrepreneurial intentions and actions. Entrepreneurship: Theory and Practice, 39(3), 655-674. http://doi.org/10.1111/etap.12056

Kirchler, E. (2007). The economic psychology of tax behaviour. Law \& Society Review, 42(4), 942-944. http://doi.org/10.1017/CBO9780511628238

Kirchler, E., Hoelzl, E., \& Wahl, I. (2008). Enforced versus voluntary tax compliance: The "slippery slope" framework. Journal of Economic Psychology, 29(2), 210-225. http://doi.org/10.1016/j.joep.2007.05.004

Langham, J., Paulsen, N., \& Hartel, C. E. J. (2012). Improving tax compliance strategies: Can the theory of planned behaviour predict business compliance? eJournal of Tax Research, 10(2), 364-402. http://doi.org/http://www.asb.unsw.edu.au/research/publications/ejournaloftaxresearch/Pages/curre ntissue.aspx

Musau, N. (2015). Determinants of tax compliance among small and medium enterprises in Kenya: A case of Nairobi county, (December).

Naibei, K., Siringi, E. M., \& Musonera, E. (2011). Impact of electronic tax registers on VAT compliance: A study of private business firms. African Research Review, 5(18), 73-88. http://doi.org/10.4314/afrrev.v5i1.64511

Nkwe, N. (2013). Tax payers ' attitude and compliance behavior among Small Medium Enterprises (SMEs) in Botswana. Business and Management Horizons, 1(1), 113-137.

Nyamwanza, T., Mavhiki, S., Mapetere, D., \& Nyamwanza, L. (2014). An analysis of SMEs' attitudes and practices toward tax compliance in Zimbabwe. Sage, 10, 26. http://doi.org/10.1177/2158244014542776

Okoyeuzu, C. (2013). Value added tax remittance: Observations from developing countries. Global Conference of Management and Business Research Finance, 13(9). Retrieved from https://www.zra.org.zm/commonHomePage.htm?viewName=ValueAddedTax

Oladipupo, A. O., \& Izedonmi, F. P. (2013). Public perception and attitude towards value added tax (VAT) in Nigeria. Www.Scirp.Org/Journal/Lib, 5(December), 126-135.

Poppelwell, E., Kelly, G., \& Wang, X. (2012). Intervening to reduce risk : identifying sanction thresholds among SME tax debtors, 10(2), 403-435.

PwC. (2014). FIRS drives nationwide VAT \& WHT verification exercise: Nigeria tax alert, (March). Retrieved from www.pwc.com

Richardson, G. (2006). Determinants of tax evasion: A cross-country investigation. Journal of International Accounting, Auditing and Taxation, 15(2), 150-169. http://doi.org/10.1016/j.intaccaudtax.2006.08.005

Saad, N. (2011). Fairness perceptions and compliance behaviour: Taxpayers' judgments in selfassessment environments. PhD Thesis, 549.

Salman, A. Y. (2011). Value added tax and economic growth of Nigeria. European Journal of ..., (August), 1-69. Retrieved from http://www.journalsbank.com/ejhss_10_4.pdf

Sekaran, U., \& Bougie, R. (2010). Research method for business: A skill building approach. John Wiley \& Sons Inc.

Shaharuddin, N., \& Palil, M. (2012). Sole proprietorphip and tax compliance intention in self assessment system: A theory of planned behavior approach. International Journal of Business, Economics and Law, 1(July 2012), 34-42.

St. John, F., Edwards-Jones, G., \& Jones, J. P. G. (2010). Conservation and human behaviour: Lessons from social psychology. Wildlife Research, 37(8), 658-667. http://doi.org/10.1071/WR10032

Swistak, A. (2016). Tax penalties in SME tax compliance. Financial Theory and Practice, 40(1), 129147. http://doi.org/10.3326/fintp.40.1.4 
Terry, D. J., Hogg, M. a, \& White, K. M. (1999). The theory of planned behaviour: Self-identity, social identity and group norms. The British Journal of Social Psychology / the British Psychological Society, 38 ( Pt 3), 225-244. http://doi.org/10.1348/014466699164149

Tijjani, M. (2016). Adeosun: Raising vat will penalize the innocent. Retrieved from https://www.thecable.ng

Trivedi, V. U., Shehata, M., \& Mestelman, S. (2005). Attitudes, incentives, and tax compliance. Department of Economics, McMaster University. http://doi.org/10.1017/CBO9781107415324.004

Walsh, K. (2012). Understanding taxpayer behaviour - New opportunities for tax administration. The Economic and Social Review, 43(3), 451-475. Retrieved from http://www.esr.ie/article/view/46

Webley, P., Adams, C., \& Elffers, H. (2002). VAT compliance in the United Kingdom, (41). Retrieved from http://hdl.handle.net/1885/42664

Webley, P., Adams, C., \& Elffers, H. (2004). Value added tax compliance. Paper Presented at the conference "Behavioral Public Finance: Toward a New Agenda", Universty of Michigan Business School, Ann Arbor., 1-36.

Webley, P., \& Ashby, J. (2010). The economic psychology of value added tax compliance. Accessed on May 7, 2014. Available from http://www.routledge.com/books/details/9780415576987/, 1-30. http://doi.org/10.4324/9780203851616

Wenzel, M. (2001). Misperception of social norms about tax compliance (1): A prestudy, (753).

Wenzel, M. (2004). The social side of sanctions: Personal and social norms as moderators of deterrence. American Psychology-Law Society (AP-LS), 28(5), 547-567. Retrieved from http://www.jstor.org/stable/4141719

White, K. M., Smith, J. R., Terry, D. J., Greenslade, J. H., \& McKimmie, B. M. (2009). Social influence in the theory of planned behaviour: The role of descriptive, injunctive, and ingroup norms. The British Journal of Social Psychology / the British Psychological Society, 48(Pt 1), 135-158. http://doi.org/10.1348/014466608X295207 